\title{
Screening of Radio-resistant Lactic Acid Bacteria
}

\author{
E-Nam Hwang, Sang-Mo Kang, Jae-Kyung Kim¹, Ju-Woon Lee ${ }^{1}$, and Jong-Heum Park ${ }^{1 *}$ \\ Department of Microbial Engineering, Konkuk University, Seoul 143-701, Korea \\ ${ }^{1}$ Advanced Radiation Technology Institute, Korea Atomic Energy Research Institute, Jeongeup 580-185, Korea
}

\begin{abstract}
This study screened for radio-resistant strains lactic acid bacteria (LAB) by evaluating their capability to survive exposure to ionizing radiation. Ten strains of LAB - Lactobacillus bulgaricus, Lactobacillus paracasei, Lactobacillus casei, Lactobacillus acidophilus, Lactobacillus plantarum, Lactobacillus delbruekii, Lactococcus lactis, Streptococcus thermophilus, Bifidobacterium breve, and Pediocuccos pentosaceus - were selected and subcultuted twice. The LAB was then further cultured for $3 \mathrm{~d}$ at $37^{\circ} \mathrm{C}$ to reach 7-10 Log colony-forming units (CFU)/mL prior to irradiation and immediately exposed to gamma rays or electron beams with absorbed doses of $0,1,2,3,4,5,6,8$, and $10 \mathrm{kGy}$. Gamma irradiation gradually decreased the number of the tested viable $\mathrm{LAB}$, and the effect was irradiation dose dependent. A similar effect was found in electron beam-irradiated LAB. Radiation sensitivity of LAB was calculated as $\mathrm{D}_{10}$ values, which ranged from $0.26 \mathrm{kGy}$ to $0.9 \mathrm{kGy}$ and $0.5 \mathrm{kGy}$ to $1.44 \mathrm{kGy}$ with exposure to gamma and electron beam irradiation, respectively, in all tested LAB. $L$. acidophilus was the most resistant to gamma and electron beam irradiation, with $\mathrm{D}_{10}$ values of $0.9 \mathrm{kGy}$ and $1.44 \mathrm{kGy}$, respectively. These results suggest that $L$. acidophilus might be suitable for the preparation of probiotics as direct-fed microbes for astronauts in extreme space environments.
\end{abstract}

Key words: ionizing irradiation, lactic acid bacteria (LAB), Lactobacillus acidophilus, radio-resistant

\section{Introduction}

Lactic acid bacteria (LAB) are microorganisms that have been used extensively in the preparation of fermented food products such as cheese, bread, yogurt, butter, and vinegar. These bacteria have also been used to extend the shelf life of foods by eliminating or reducing the growth of harmful pathogens during storage.

The most commonly used LAB are species of Lactobacillus, Bifidobacterium, Streptococcus, and Enterococcus (Parvez et al., 2006). These microorganisms are naturally present in the gastrointestinal microecology of healthy individuals and have been shown to improve intestinal health, reduce symptoms of lactose intolerance, and lower serum cholesterol, which decreases the risk of certain cancers and enhances immunity (Isolauri et al., 2004).

Owing to these beneficial effects of LAB, their use in the food industry is increasing. Fermented milk products were introduced commercially in Korea in 1971, and the sale of products using LAB generated an estimated half a

\footnotetext{
*Corresponding author: Jong-Heum Park, Advanced Radiation Technology Institute, Korea Atomic Energy Research Institute, Jungeup 580-185, Korea. Tel: 82-63-570-3244, Fax: 82-63-5703218, E-mail: jhpark21@kaeri.re.kr
}

billion dollars in 2010. The market share of these products is expected to grow at an annual rate of $10 \%$ (Youn and Jeong, 2010). This increase is primarily attributable to consumer demand for natural materials as sources of products for prolonged physical well-being and their recognition that health foods have therapeutic benefits including prophylaxis for some intestinal infections (Arendt et al., 2011; Clark et al., 2012; Kumar et al., 2012; Mercenier et al., 2002). The Korea Food and Drug Administration (2012) has also designated probiotics using LAB as health supplement foods. Therefore, the development of new probiotic products through the screening of biofunctional activities from useful LAB is expected to increase with their increasing market values.

LAB can be helpful in maintaining astronaut health. Safety from infection in space environments is one of the main issues in space crew medical support (Ilyin, 2005). Although the susceptibility of astronauts to infection with pathogenic bacteria during space flights has not been confirmed, reports have demonstrated sharp decreases in LAB such as intestinal lactobacilli and bifidobacteria (Ilyin, 2005) and a need for greater concentrations of chemotherapeutic agents (i.e., antibiotics) (Leys et al., 2004), both of which can result in the bodily deterioration of astronauts during missions. LAB is a biotherapeutic agent 
that suppresses the increase in virulence during microfloral proliferation. Providing these probiotics to astronauts during space flight may improve their capabilities under extremely stressful space conditions such as exposure to microgravity or low doses of cosmic rays. However, exposure to cosmic rays might inactivate or mutate $\mathrm{LAB}$ (Horneck et al., 1989) and thus affect their beneficial effects in humans. Therefore, the identification of radiation-resistant $\mathrm{LAB}$ strains is required before probiotics can be prepared as direct-fed microbes for astronauts.

In this study, LAB used for the production of fermented milk products were tested for their capability to survive exposure to ionizing radiation, and were screened for the selection of radiation-resistant strains suitable for the preparation of probiotics as direct-fed microbes for astronauts in extreme space environments.

\section{Materials and Methods}

\section{Strains and culture medium}

Ten LAB stains - Lactobacillus delbrueckii subsp. bulgaricus (KCTC3635), Lactobacillus paracasei (KCTC 13169), Lactobacillus casei (KCTC3109), Lactobacillus acidophilus (KCTC3140), Lactobacillus plantarum (KCTC 3103), Lactobacillus delbrueckii (KCTC13730), Lactococcus lactis (KCTC2013), Streptococcus salivarius subsp. thermophilus (KCTC3658), Bifidobacterium breve (KCTC 3419), Pediococcus pentosaceus (KCTC3116) - were obtained from the Korean Collection for Type Cultures (KCTC) at the Korea Research Institute of Bioscience and Biotechnology (Korea).

Brain Heart Infusion (BHI) broth (Difco, USA) was used for the culture of $S$. thermophilus and L. lactis, and de Man, Rogosa, and Sharpe (MRS) broth (Difco) was used for the culture of the other 8 strains. The LAB strains were frozen and stored at $-70^{\circ} \mathrm{C}$ in $10 \%$ glycerol containing BHI or MRS broth until use.

\section{Preparation of LAB samples}

Ten LAB strains were subcultured twice in MRS or BHI broth. Then, $1 \%$ subculture LAB suspensions were inoculated and cultured for $3 \mathrm{~d}$ at $37^{\circ} \mathrm{C}$ to reach 7-10 Log colony-forming units $(\mathrm{CFU}) / \mathrm{mL}$. The LAB culture suspensions obtained were divided into 1-mL aliquots in Eppendorf tubes. Each of the LAB aliquot samples was exposed to gamma or electron beam irradiation.

\section{Gamma and electron beam irradiation}

LAB samples were irradiated with gamma or electron beams at doses of $0,1,2,3,4,5,6,8$, and $10 \mathrm{kGy}$. For gamma irradiation, a cobalt-60 irradiator (IR-79; Nordion International Ltd., Canada) with a source strength of 11.1 $\mathrm{PBq}$ was used. For electron beam irradiation, an ELV4electron accelerator (energy, $10 \mathrm{MeV}$; beam power, $570 \mathrm{~kW}$ ) was used with a beam current of $1 \mathrm{~mA}$. Dosimetry was performed using an alanine dosimeter $(5 \mathrm{~mm}$; Bruker Instruments, Germany) for gamma irradiation and a ceric-cerous dosimeter (Bruker Instruments, Germany) for electron beam irradiation, respectively. The error of the total adsorbed doses in the LAB samples was within $5 \%$. The irradiated LAB samples were immediately subjected to viability tests.

\section{Viability test of irradiated LAB}

After irradiation, LAB samples were serially diluted in sterilized saline, plated on solid MRS medium, and incubated for $3 \mathrm{~d}$ at $37^{\circ} \mathrm{C}$. Streptococcus thermophilus and $L$. lactis were incubated on solid $\mathrm{BHI}$ medium. LAB viability was expressed as mean Log CFU (suspension $\mathrm{mL}$ ) \pm standard deviation of triplicate measurements. $\mathrm{D}_{10}$ values, defined as radiation dose $(\mathrm{kGy})$ required to reduce the number of CFU by $1 \log _{10}$, were determined by calculating the negative reciprocal of the slope of the linear regression curve (Aziz et al., 1997; Bari et al., 2003; Rajkowski et al., 2003).

\section{Statistical analysis}

Statistical analysis of the data was carried out with 1way analysis of variance using SPSS 19.0 software (SPSS Inc, USA), and significantly different means were compared using the multiple range test of Duncan. A $p$ value of $<0.05$ was considered statistically significant.

\section{Results and Discussion}

\section{Irradiation effect on viability of LAB}

The effects of gamma irradiation on the viability of the 10 LAB strains studied is provided in Table 1 . The viability of non-irradiated $\mathrm{LAB}$ cultivated for $3 \mathrm{~d}$ ranged from a mean $7.3 \mathrm{Log} C F U / \mathrm{mL}$ to a mean $10.9 \mathrm{Log} \mathrm{CFU} / \mathrm{mL}$. Gamma irradiation significantly decreased the viability of LAB $(p<0.05)$, and LAB viability decreased with increases in gamma radiation dose. The viability of all $\mathrm{LAB}$ strains tested was abrogated at $5.0 \mathrm{kGy}$ with the exception of L. acidophilus, which was abrogated at $10.0 \mathrm{kGy}$. This result agrees with a previous report that $L$. acidophilus is not easily sterilized by exposure to ionizing radiation (Morichi, 1997). Therefore, L. acidophilus was con- 
Table 1. Radiation sensitivity of lactic acid bacteria against gamma ray

\begin{tabular}{|c|c|c|}
\hline Lactic acid bacteria & $\begin{array}{l}\text { Irradiating } \\
\text { dose }(\mathrm{kGy})\end{array}$ & $\begin{array}{l}\text { Viable cell No. } \\
\text { (Log CFU/mL) }\end{array}$ \\
\hline \multirow{6}{*}{$\begin{array}{l}\text { Lactobacillus delbrueckii } \\
\text { subsp. bulgaricus }\end{array}$} & 0 & $7.47 \pm 0.02^{\mathrm{a}}$ \\
\hline & 1 & $5.81 \pm 0.04^{\mathrm{b}}$ \\
\hline & 2 & $4.66 \pm 0.19^{c}$ \\
\hline & 3 & $2.99 \pm 0.09^{\mathrm{d}}$ \\
\hline & 4 & $1.27 \pm 0.03^{\mathrm{e}}$ \\
\hline & 5 & ND \\
\hline \multirow{6}{*}{ Lactobacillus paracasei } & 0 & $10.97 \pm 0.10^{\mathrm{a}}$ \\
\hline & 1 & $6.74 \pm 0.11^{\mathrm{b}}$ \\
\hline & 2 & $4.84 \pm 0.04^{\mathrm{c}}$ \\
\hline & 3 & $2.75 \pm 0.21^{\mathrm{d}}$ \\
\hline & 4 & $1.15 \pm 0.21^{\mathrm{e}}$ \\
\hline & 5 & ND \\
\hline \multirow{6}{*}{ Lactobacillus casei } & 0 & $8.81 \pm 0.04^{\mathrm{a}}$ \\
\hline & 1 & $8.23 \pm 0.06^{\mathrm{b}}$ \\
\hline & 2 & $6.51 \pm 0.03^{\mathrm{c}}$ \\
\hline & 3 & $3.82 \pm 0.18^{\mathrm{d}}$ \\
\hline & 4 & $1.00 \pm 0.01^{\mathrm{e}}$ \\
\hline & 5 & ND \\
\hline \multirow{8}{*}{ Lactobacillus acidophilus } & 0 & $9.67 \pm 0.04^{\mathrm{a}}$ \\
\hline & 1 & $8.92 \pm 0.06^{\mathrm{b}}$ \\
\hline & 2 & $8.37 \pm 0.02^{\mathrm{c}}$ \\
\hline & 3 & $6.94 \pm 0.04^{\mathrm{d}}$ \\
\hline & 4 & $5.86 \pm 0.15^{\mathrm{e}}$ \\
\hline & 6 & $2.75 \pm 0.05^{\mathrm{f}}$ \\
\hline & 8 & $0.97 \pm 0.03^{\mathrm{g}}$ \\
\hline & 10 & ND \\
\hline \multirow{6}{*}{ Lactobacillus plantarum } & 0 & $9.69 \pm 0.05^{\mathrm{a}}$ \\
\hline & 1 & $7.17 \pm 0.04^{\mathrm{b}}$ \\
\hline & 2 & $4.29 \pm 0.15^{\mathrm{c}}$ \\
\hline & 3 & $3.57 \pm 0.04^{\mathrm{d}}$ \\
\hline & 4 & $0.15 \pm 0.21^{\mathrm{e}}$ \\
\hline & 5 & ND \\
\hline \multirow{6}{*}{ Lactobacillus delbrueckii } & 0 & $7.38 \pm 0.12^{\mathrm{a}}$ \\
\hline & 1 & $6.58 \pm 0.11^{\mathrm{b}}$ \\
\hline & 2 & $6.10 \pm 0.12^{\mathrm{c}}$ \\
\hline & 3 & $2.15 \pm 0.21^{\mathrm{d}}$ \\
\hline & 4 & $1.43 \pm 0.49^{\mathrm{e}}$ \\
\hline & 5 & ND \\
\hline \multirow{5}{*}{ Lactococcus lactis } & 0 & $8.95 \pm 0.27^{\mathrm{a}}$ \\
\hline & 1 & $5.85 \pm 0.06^{\mathrm{b}}$ \\
\hline & 2 & $4.50 \pm 0.13^{\mathrm{c}}$ \\
\hline & 3 & $3.97 \pm 0.35^{\mathrm{d}}$ \\
\hline & 4 & ND \\
\hline \multirow{6}{*}{$\begin{array}{l}\text { Streptocuccus salivarius } \\
\text { subsp. theromphilus }\end{array}$} & 0 & $9.14 \pm 0.07^{\mathrm{a}}$ \\
\hline & 1 & $7.28 \pm 0.14^{b}$ \\
\hline & 2 & $6.22 \pm 0.05^{\mathrm{c}}$ \\
\hline & 3 & $3.65 \pm 0.07^{\mathrm{d}}$ \\
\hline & 4 & $0.38 \pm 0.12^{\mathrm{e}}$ \\
\hline & 5 & ND \\
\hline \multirow{4}{*}{ Bifidobacterium breve } & 0 & $10.65 \pm 0.05^{\mathrm{a}}$ \\
\hline & 1 & $4.93 \pm 0.02^{\mathrm{b}}$ \\
\hline & 2 & $2.87 \pm 0.15^{\mathrm{c}}$ \\
\hline & 3 & ND \\
\hline
\end{tabular}

Table 1. Continued

\begin{tabular}{ccc}
\hline \hline Lactic acid bacteria & $\begin{array}{c}\text { Irradiating } \\
\text { dose }(\mathrm{kGy})\end{array}$ & $\begin{array}{c}\text { Viable cell No. } \\
(\text { Log CFU/mL) }\end{array}$ \\
\hline & 0 & $9.34 \pm 0.01^{\mathrm{a}}$ \\
Pedicoccus pentosaceus & 1 & $8.66 \pm 0.08^{\mathrm{b}}$ \\
& 2 & $7.45 \pm 0.06^{\mathrm{c}}$ \\
& 3 & $5.01 \pm 0.16^{\mathrm{d}}$ \\
& 5 & $2.37 \pm 0.02^{\mathrm{e}}$ \\
& 5 & $\mathrm{ND}$ \\
\hline
\end{tabular}

firmed to be the most resistant to gamma irradiation among the $10 \mathrm{LAB}$ strains tested.

In a parallel experiment, the effects of electron beam irradiation on LAB viability was measured (Table 2). The viability of the non-irradiated $\mathrm{LAB}$ cultivated for $3 \mathrm{~d}$ ranged from a mean 7.2 Log CFU/mL to a mean $10.2 \mathrm{Log}$ $\mathrm{CFU} / \mathrm{mL}$. Similar to gamma irradiation, electron beam irradiation significantly decreased $(p<0.05)$ the viability of these LAB and the rate of decreased viability was positively correlated with the increase in electron beam radiation dose. However, unlike gamma irradiation, electron beam irradiation abrogated the viability of LAB at $6.0 \mathrm{kGy}$ with the exception of $L$. acidophilus and P. pentosaceus. The latter was sterilized at $8.0 \mathrm{kGy}$, but the former was not eliminated at even $10.0 \mathrm{kGy}$. This result demonstrates that $L$. acidophilus is highly resistant to gamma irradiation as well as electron beam irradiation.

\section{Radiation sensitivity of LAB}

$\mathrm{D}_{10}$ values of the 10 studied LAB strains exposed to gamma irradiation are provided in Table 3 . The $\mathrm{D}_{10}$ values of these bacteria ranged from $0.26 \mathrm{kGy}$ and $0.90 \mathrm{kGy}$ in a rank order of L. acidophilus $(0.90 \mathrm{kGy})>L$. bulgaricus $(0.66 \mathrm{kGy})>$ L. lactis $(0.61 \mathrm{kGy})=$ L. delbrueckii $(0.61$ $\mathrm{kGy})>$ P. pentosaceus $(0.57 \mathrm{kGy})>$ L. casei $(0.51 \mathrm{kGy})>$ $S$. thermophilus $(0.47 \mathrm{kGy})>$ L. plantarum $(0.44 \mathrm{kGy})>$ B. breve $(0.26 \mathrm{kGy})$.

$\mathrm{D}_{10}$ values of LAB exposed to electron beam irradiation were also calculated (Table 4) and ranged from 0.50 to $1.44 \mathrm{kGy}$. The rank order of $\mathrm{D}_{10}$ values of electron beamirradiated LAB was $L$. acidophilus $(1.44 \mathrm{kGy})>B$. breve $(0.82 \mathrm{kGy})>P$. pentosaceus $(0.80 \mathrm{kGy})>L$. casei $(0.68$ $\mathrm{kGy})>$ L. paracasei $(0.64 \mathrm{kGy})>S$. thermophilus $(0.59$ $\mathrm{kGy})=$ L. delbrueckii $(0.59 \mathrm{kGy})>$ L. lactis $(0.57 \mathrm{kGy})>$ L. plantarum $(0.50 \mathrm{kGy})=$ L. bulgaricus $(0.50 \mathrm{kGy})$.

Previous reports have indicated that the type of $\mathrm{LAB}$ strain and the radiation source affect the radiation sensitivity of LAB. For example, Hastings et al. (1986) have shown that $\mathrm{D}_{10}$ values of $L$. plantarum and $L$. casei isolated from gamma-irradiated minced meats are $0.46 \mathrm{kGy}$, 
Table 2. Radiation sensitivity of lactic acid bacteria against electron beam

\begin{tabular}{|c|c|c|}
\hline Lactic acid bacteria & $\begin{array}{l}\text { Irradiating } \\
\text { dose }(k G y)\end{array}$ & $\begin{array}{l}\text { Viable cell No. } \\
\text { (Log CFU/mL) }\end{array}$ \\
\hline \multirow{5}{*}{$\begin{array}{l}\text { Lactobacillus delbrueckii } \\
\text { subsp. bulgaricus }\end{array}$} & 0 & $7.66 \pm 0.10^{\mathrm{a}}$ \\
\hline & 1 & $5.64 \pm 0.23^{b}$ \\
\hline & 2 & $3.41 \pm 0.10^{\mathrm{c}}$ \\
\hline & 3 & $1.68 \pm 0.25^{\mathrm{d}}$ \\
\hline & 4 & ND \\
\hline \multirow{8}{*}{ Lactobacillus paracasei } & 0 & $10.21 \pm 0.29^{\mathrm{a}}$ \\
\hline & 1 & $10.10 \pm 0.04^{\mathrm{a}}$ \\
\hline & 2 & $7.13 \pm 0.04^{b}$ \\
\hline & 3 & $5.94 \pm 0.11^{\mathrm{c}}$ \\
\hline & 4 & $4.37 \pm 0.02^{\mathrm{d}}$ \\
\hline & 5 & $2.58 \pm 0.01^{\mathrm{e}}$ \\
\hline & 6 & $1.49 \pm 0.20^{\mathrm{f}}$ \\
\hline & 8 & ND \\
\hline \multirow{7}{*}{ Lactobacillus casei } & 0 & $9.17 \pm 0.05^{\mathrm{a}}$ \\
\hline & 1 & $8.83 \pm 0.14^{\mathrm{b}}$ \\
\hline & 2 & $6.73 \pm 0.03^{\mathrm{c}}$ \\
\hline & 3 & $5.39 \pm 0.12^{\mathrm{d}}$ \\
\hline & 4 & $3.59 \pm 0.06^{\mathrm{e}}$ \\
\hline & 5 & $2.27 \pm 0.17^{\mathrm{f}}$ \\
\hline & 6 & ND \\
\hline \multirow{9}{*}{ Lactobacillus acidophilus } & 0 & $8.70 \pm 0.06^{\mathrm{a}}$ \\
\hline & 1 & $8.65 \pm 0.07^{\mathrm{a}}$ \\
\hline & 2 & $6.82 \pm 0.07^{\mathrm{b}}$ \\
\hline & 3 & $6.03 \pm 0.02^{\mathrm{c}}$ \\
\hline & 4 & $4.86 \pm 0.07^{\mathrm{d}}$ \\
\hline & 5 & $4.83 \pm 0.07^{\mathrm{d}}$ \\
\hline & 6 & $4.58 \pm 0.13^{\mathrm{e}}$ \\
\hline & 8 & $2.89 \pm 0.04^{\mathrm{f}}$ \\
\hline & 10 & $1.95 \pm 0.16^{\mathrm{g}}$ \\
\hline \multirow{5}{*}{ Lactobacillus plantarum } & 0 & $7.66 \pm 0.10^{\mathrm{a}}$ \\
\hline & 1 & $5.64 \pm 0.23^{\mathrm{b}}$ \\
\hline & 2 & $3.41 \pm 0.10^{\mathrm{c}}$ \\
\hline & 3 & $1.68 \pm 0.25^{\mathrm{d}}$ \\
\hline & 4 & ND \\
\hline \multirow{7}{*}{ Lactobacillus delbrueckii } & 0 & $9.12 \pm 0.01^{\mathrm{a}}$ \\
\hline & 1 & $8.79 \pm 0.01^{\mathrm{b}}$ \\
\hline & 2 & $5.87 \pm 0.33^{\mathrm{c}}$ \\
\hline & 3 & $4.78 \pm 0.10^{\mathrm{d}}$ \\
\hline & 4 & $2.79 \pm 0.01^{\mathrm{e}}$ \\
\hline & 5 & $1.00 \pm 0.00^{\mathrm{f}}$ \\
\hline & 6 & ND \\
\hline \multirow{6}{*}{ Lactococcus lactis } & 0 & $8.82 \pm 0.07^{\mathrm{a}}$ \\
\hline & 1 & $5.17 \pm 0.06^{\mathrm{b}}$ \\
\hline & 2 & $3.97 \pm 0.08^{c}$ \\
\hline & 3 & $2.40 \pm 0.05^{\mathrm{d}}$ \\
\hline & 4 & $1.50 \pm 0.35^{\mathrm{e}}$ \\
\hline & 5 & ND \\
\hline \multirow{5}{*}{$\begin{array}{l}\text { Streptocuccus salivarius } \\
\text { subsp. theromphilus }\end{array}$} & 0 & $7.25 \pm 0.08^{\mathrm{a}}$ \\
\hline & 1 & $5.77 \pm 0.05^{\mathrm{b}}$ \\
\hline & 2 & $3.20 \pm 0.07^{\mathrm{c}}$ \\
\hline & 3 & $2.44 \pm 0.09^{\mathrm{d}}$ \\
\hline & 4 & ND \\
\hline
\end{tabular}

Table 2. Continued

\begin{tabular}{ccc}
\hline \hline Lactic acid bacteria & $\begin{array}{c}\text { Irradiating } \\
\text { dose }(\mathrm{kGy})\end{array}$ & $\begin{array}{c}\text { Viable cell No. } \\
(\text { Log CFU/mL) }\end{array}$ \\
\hline Streptocuccus salivarius & 0 & $7.25 \pm 0.08^{\mathrm{a}}$ \\
subsp. theromphilus & 1 & $5.77 \pm 0.05^{\mathrm{b}}$ \\
& 2 & $3.20 \pm 0.07^{\mathrm{c}}$ \\
& 3 & $2.44 \pm 0.09^{\mathrm{d}}$ \\
Bifidobacterium breve & 0 & $\mathrm{ND}$ \\
\hline & 1 & $8.43 \pm 0.01^{\mathrm{a}}$ \\
& 2 & $6.04 \pm 0.03^{\mathrm{a}}$ \\
& 3 & $4.84 \pm 0.03^{\mathrm{b}}$ \\
& 4 & $3.79 \pm 0.09^{\mathrm{d}}$ \\
& 5 & $2.70 \pm 0.65^{\mathrm{e}}$ \\
& 6 & $\mathrm{ND}$ \\
\hline \multirow{3}{*}{ Pedicoccus pentosaceus } & 0 & $9.43 \pm 0.22^{\mathrm{a}}$ \\
& 1 & $8.93 \pm 0.01^{\mathrm{b}}$ \\
& 2 & $6.96 \pm 0.01^{\mathrm{c}}$ \\
& 3 & $5.92 \pm 0.05^{\mathrm{d}}$ \\
& 4 & $4.99 \pm 0.05^{\mathrm{e}}$ \\
& 5 & $3.47 \pm 0.01^{\mathrm{f}}$ \\
& 6 & $2.06 \pm 0.11^{\mathrm{g}}$ \\
& 8 & $\mathrm{ND}$ \\
\hline
\end{tabular}

and Byun (2009) have found that $\mathrm{D}_{10}$ values of Lactobacillus spp. varied from $0.23 \mathrm{kGy}$ to $0.38 \mathrm{kGy}$. In this study, $\mathrm{D}_{10}$ values in the $10 \mathrm{LAB}$ strains varied from 0.26 $\mathrm{kGy}$ to $0.90 \mathrm{kGy}$ with exposure to gamma irradiation and from $0.50 \mathrm{kGy}$ to $1.44 \mathrm{kGy}$ with exposure to electron beam irradiation. In particular, the $\mathrm{D}_{10}$ values of $L$. acidophilus, $P$. pentosaceus, and B. breve greatly increased from $0.90 \mathrm{kGy}$, $0.57 \mathrm{kGy}$, and $0.26 \mathrm{kGy}$, respectively, with exposure to gamma irradiation to $1.44 \mathrm{kGy}, 0.80 \mathrm{kGy}$, and $0.82 \mathrm{kGy}$, respectively, against electron beam irradiation (Tables 3 and 4). This difference reflects that even LAB with identical sensitivity to radiation can display differences related to the temperature at which irradiation occurs, culture medium composition, growth phase, oxygen content during cultivation, and other conditions (Molins, 2001).

Our results show that among $10 \mathrm{LAB}, L$. acidophilus was the most radio-resistant strain. Lactobacillus acidophilus is one of many common probiotics used for the preparation of fermented milk products, and it has diverse biological activities. The LAB examined in our study can suppress the growth of a variety of harmful pathogens (Aween et al., 2012; Millette et al., 2007) and alleviate irritable colon syndrome (Sinn et al., 2008). These bacteria also induce immune-modulating activities such as Tcell immune response (Wen et al., 2012), chemokine production (Jiang et al., 2012), and anti-cancer immune responses (Chen at el., 2012; Maroof et al., 2012). Moreover, $L$. acidophilus can reduce cholesterol absorption in 
Table 3. $D_{10}$ value of lactic acid bacteria by gamma-irradiation

\begin{tabular}{ccc}
\hline \hline Lactic acid bacteria & $\begin{array}{c}\mathrm{D}_{10} \\
(\mathrm{kGy})\end{array}$ & $\mathrm{R}^{2}$ \\
\hline Lactobacillus delbrueckii subsp. bulgaricus & 0.66 & 0.99 \\
Lactobacillus paracasei & 0.42 & 0.96 \\
Lactobacillus casei & 0.51 & 0.51 \\
Lactobacillus acidophilus & 0.90 & 0.96 \\
Lactobacillus plantarum & 0.44 & 0.97 \\
Lactobacillus delbrueckii & 0.61 & 0.61 \\
Lactococcus lactis & 0.61 & 0.89 \\
Streptocuccus salivarius subsp. theromphilus & 0.47 & 0.96 \\
Bifidobacterium breve & 0.26 & 0.93 \\
Pedicoccus pentosaceus & 0.57 & 0.94 \\
\hline
\end{tabular}

Table 4. $D_{10}$ value of lactic acid bacteria by electron beamirradiation

\begin{tabular}{ccc}
\hline \hline Lactic acid bacteria & $\begin{array}{c}\mathrm{D}_{10} \\
(\mathrm{kGy})\end{array}$ & $\mathrm{R}^{2}$ \\
\hline Lactobacillus delbrueckii subsp. bulgaricus & 0.50 & 0.90 \\
Lactobacillus paracasei & 0.64 & 0.98 \\
Lactobacillus casei & 0.68 & 0.98 \\
Lactobacillus acidophilus & 1.44 & 0.95 \\
Lactobacillus plantarum & 0.50 & 0.99 \\
Lactobacillus delbrueckii & 0.59 & 0.98 \\
Lactococcus lactis & 0.57 & 0.93 \\
Streptocuccus salivarius subsp. theromphilus & 0.59 & 0.96 \\
Bifidobacterium breve & 0.82 & 0.98 \\
Pedicoccus pentosaceus & 0.80 & 0.98 \\
\hline
\end{tabular}

cells (Huang and Zheng, 2010), ameliorate H. pyloriinduced gastric inflammation (Yang et al., 2012), and induce antidiabetic effects in combination with $L$. casei (Yadav et al., 2007).

$\mathrm{LAB}$ are safe microorganisms with a long history of use in the preparation of popular fermented milk products. These bacteria also have health-promoting advantages via various biological mechanisms. The number of fermented milk products containing these bio-functional properties is increasing.

In this study, 10 LAB used in the production of fermented milk products were tested for their capability to survive exposure to ionizing radiation. Among those LAB strains, $L$. acidophilus was the most radio-resistant to gamma and electron beam irradiation. These results suggest that $L$. acidophilus might be a suitable candidate for the preparation of probiotics as direct-fed microbes for astronauts in extreme space environments.

\section{Acknowledgements}

This research was co-supported by the National Research Foundation in the Nuclear Research \& Development Prog- ram and by the Basic Research Support Program of Korea Atomic Energy Research Institute.

\section{References}

1. Arendt, E. K., Moroni, A., and Zannini, E. (2011) Medical nutrition therapy: use of sourdough lactic acid bacteria as a cell factory for delivering functional biomolecules and food ingredients in gluten free bread. Microb. Cell Fact. 10(suppl 1), S15.

2. Aween, M. M., Hassan, Z., Muhialdin, B. J., Eljamel, Y. A., Al-Mabrok, A. S., and Lani, M. N. (2012) Antibacterial activity of Lactobacillus acidophilus strains isolated from honey maketed in Malaysia against selected multiple antibiotic resistant (MAR) gram-positive bacteria. J. Food Sci. 77, M364M367.

3. Aziz, N. H., El-Fouly, M. Z., Abu-Shady, M. R., and Moussa, L. A. A. (1997) Effect of gamma radiation on the survival of fungal and actinomycetal florae contaminating medicinal plants. Appl. Radiat. Isot. 48, 71-76.

4. Bari, M. L., Nazuka, E., Sabina, Y., Todoriki, S., and Isshiki, K. (2003) Chemical and irradiation treatments for killing Escherichia coli $\mathrm{O} 157: \mathrm{H} 7$ on alfalfa, radish, and mung bean seeds. J. Food Prot. 66, 767-774.

5. Byun, M. W. (2009) Current status and prospects of radiation technology for food safety and food security. Bangsaseon San Eob Haghoeji 3, 145-160.

6. Chen, C. C., Lin, W. C., Kong, M. S., Shi, H. N., Walker, W. A., Lin, C. Y., Huang, C. T., Lin, Y. C., Jung, S. M., and Lin, T. Y. (2012) Oral inoculation of probiotics Lactobacillus acidophilus NCFM suppresses tumor growth both in segmental orthotopic colon cancer and extra-intestinal tissue. Br. J. Nutr. 107, 1623-1634.

7. Clark, G., Cryan, J. F., Dinan, T. G., and Quigley, E. M. (2012) Probiotics for the treatment of irritable bowel syndrome- Focus on lactic acid bacteria. Aliment Pharnacol. Ther. 35, 403-413.

8. Hastings, J. W., Holzapfel, W. H., and Noemand, J. G. (1986) Radiation resistance of Lactobacilli isolated from radurized meat relative to growth and environment. Appl. Environ. Microbiol. 52, 898-901.

9. Horneck, G., Sshafer, M., Baltschukat, K., Weisbrod, U., Micke, U., Facius, R., and Bucker, H. (1989). Cell inactivation, repair, and mutation induction in bacteria after heavy ion exposure: Results from experiments at accelerations and in space. Adv. Space Res. 9, 105-116.

10. Huang, Y. and Zheng, Y. (2010) The probiotic Lactobacillus acidophilus reduces cholesterol absorption through the downregulation of Niemann-Pick C1-like 1 in Caco-2 cells. Br. $J$. Nutr. 103, 473-478.

11. Ilyin, V. K. (2005) Microbiological status of cosmonauts during orbital spaceflight on Salyut and Mir orbital stations. Acta Astonaut. 56, 839-850.

12. Isolauri, E., Salminen, S., and Ouwehand, A. C. (2004) Probiotics. Best Prac. Res. Cl. Em. 18, 299-313.

13. Jiang, Y., Lu, X., Man, C., Han, L., Shan, Y., Qu, X., Liu, Y., Yang, S., Xue, Y., and Zhang, Y. (2012) Lactobacillus acido- 
philus induces cytokine and chemokine production via NF$\mathrm{kB}$ and $\mathrm{p} 38$ mitogen-activated protein kinase signalling pathway in interstinal epithelial cells. Clin. Vaccine Immunol. 19, 603-608.

14. Korea Food and Drug Administration. Amendment of health supplemen foods 2008-12. Available from: http://www.mfds. go.kr/index.do?searchkey=title:contents\&mid $=95 \&$ searchword $=$ 건강기능식품 $\&$ division $=\&$ pageNo=5.pdf. Accessed Apr. 23, 2013.

15. Kumar, M., Nagpal, R., Kumar, R., Hemalatha, R., Verma, V., Kumar, A., Chakraborty, C., Sin, B., Marotta, F., Jain, S., and Yadav, H. (2012) Cholesterol-lowering probiotics as potential biotherapeutics for metabolic diseases. Exp. Diabetes Res. 12, 1-14.

16. Leys, N. M., Hendrickx, L., De Boever, P., Baatout, S., and Mergeay, M. (2004) Space flight effects on bacterial physiology. J. Biol. Regul. Homeost. Agent 18, 193-199.

17. Maroof, H., Hassan, Z. M., Mobarwz, A. M., and Mohamadabadi, M. A. (2012) Lactobacillus acidophilus could modulate the immune response against breast cancer in murine model. J. Clin. Immunol. 32,1353-1359.

18. Mercenier, A., Pavan, S., and Pot, B. (2002) Probiotics as biotheraeutic agents: Present knowledge and future prospects. Curr. Pharma. Design 8, 99-110.

19. Millette, M., Luquet, F. M., and Lacroix, M. (2007) In vitro growth control of selected pathogens by Lactobacillus acidophilus- and Lactobacillus casei-fermented milk. Lett. Appl. Microbiol. 44, 314-319.

20. Molins, R. A. (2001) Food irradiation: Principles and applications. John Wiley \& Sons Inc., New York. 131-191.

21. Morichi, T. (1997) Characteristic and utilization of lactic acid bacteria; progress in recent researches. Milk Sci. 46, 1-20.

22. Parvez, S., Malik, K. A., Kang, S. A., and Kim, H. Y. (2006) Probiotics and their fermented food products are beneficial for health. J. Appl. Microbiol. 100, 1171-1185.

23. Rajkowski, K. T., Boyd, G. and Thayer, D. W. (2003) Irradiation D values for Escherichia coli $\mathrm{O} 157: \mathrm{H} 7$ and Salmonella $s p$. on inoculated broccoli seeds and effects of irradiation on broccoli sprout keeping quality and seed viability. J. Food Prot. 66, 760-766.

24. Sinn, D. H., Song, J. H., Kim, H. J., Lee, J. H., Son, H. J., Chang, D. K., Kim, Y. H., Kim, J. J., Rhee, J. C., and Rhee, P. L. (2008) Therapeutic effect of Lactobailuus acidophilusSDC 2012, 2013 in patients with irritable bowel syndrome. Dig. Dis. Sci. 53, 2714-1718.

25. Wen, K., Li, G., Liu, F., Li, Y., Kocher, J., Lin, L., Yang, X., and Yuan, L. (2012) High dose and low dose Lactobacillus acidophilus exerted differential immune modulating effects on $\mathrm{T}$ cell immune responses induced by an oral human rotavirus vaccine in gnotobiotic pigs. Vaccine 30, 1198-1207.

26. Yadav, H., Jain, S., and Sinha, P. R. (2007) Antidiabetic effect of probiotic dahi containing Lactobacillus acidophilus and Lactobacillus casei in high fructose fed rats. Nutrition 23, 6268.

27. Yang, Y. J., Chuang, C. C., Yang, H. B., Lu, C. C., and Sheu, B. S. (2012) Lactobacillus acidophilus ameliorates H. pyloriinduced gastric inflammation by inactivating the $\mathrm{Smad} 7$ and NF- $\kappa$ B pathways. BMC Microbiol. 12, 38.

28. Youn, K. S. and Jeong, Y. N. Market trend in fermented milk products. Abailable from: http://www.asiatoday.co.kr/news/ view.asp?seq=356257. Accessed May 10, 2010.

(Received 2013.1.11/Revised 2013.4.29/Accepted 2013.6.3) 